\title{
EDITORIAL
}

\section{SALUD GLOBAL, NUEVOS DESAFÍOS PARA INVESTIGACIÓN EN ENFERMERÍA}

\section{GLOBAL HEALTH, NEW CHALLENGES TO NURSING RESEARCH}

\author{
Dra. LiLian Ferrer \\ Escuela de Enfermería. Pontificia Universidad Católica de Chile \\ Dra. Melissa Sutherland \\ Connell School of Nursing. Boston College \\ E-mail:1ferrerl@uc.cl, melissa.sutherland@bc.edu
}

Hablemos de salud global. Con frecuencia se escucha esta palabra en estos días. Los estudiantes de hoy quieren tener una experiencia de salud global, en mayor número los investigadores están liderando estudios en el tema y los educadores están enseñando principios de salud global en las salas de clases. Entonces, ¿qué es salud global? Y aún más ¿cómo deberíamos pensar sobre ella? Koplan (1) define Salud Global como "el área de estudio, investigación y práctica que busca, de forma prioritaria, mejorar y alcanzar equidad en salud para la población mundial".

La Salud Global es interdisciplinaria y colaborativa, enfatiza problemas que atraviesan fronteras, se enfoca en los determinantes de salud y es capaz de integrar el concepto de atención centrada en el individuo con salud de la población. Además, enfrenta grandes desafíos que requieren de colaboración transnacional y el trabajo de diversas disciplinas que puedan ser solucionados con éxito.

Las Naciones Unidas consideran dieciocho problemas de Salud Global que deberán enfrentar en las próximas décadas, entre ellas, la migración. Esta, ya sea por motivos climáticos, desastres naturales o bien por violencia, es un gran desafío que enfrentan quienes trabajan en temas de salud internacional, y para poder planificar la salud de individuos, familias y poblaciones, y ser capaces de entregar un mejor cuidado, se deberá considerar siempre la migración como un factor relevante. Las Naciones Unidas (2) definen refugiados como individuos protegidos por leyes internacionales que han tenido que dejar forzosamente su país de origen a raíz de una persecución. En contraste con ello, los migrantes son individuos y/o familias que deciden voluntariamente dejar su hogar en un país o lugar específico en busca 
de mejores condiciones de vida. Sin embargo, en ambos casos, la acción de transportarse a un nuevo país, comunidad o cultura tiene implicancias en salud tanto para el país de origen como para el receptor de estos individuos. Como afirma Carlos Van der Laat (3), la migración es un determinante en salud por sí mismo y de tal modo, tiene un rol protagónico en salud global.

Nueva evidencia certifica que hoy el mundo se enfrenta al mayor número de personas sin hogar que se ha presentado a lo largo de la historia y el planeta está siendo testigo de los más altos niveles de desplazamiento registrados. Los datos actuales muestran que cerca de 65,3 millones de personas han debido dejar sus hogares, entre ellos, 21,3 millones lo han hecho como refugiados y más de la mitad de ellos siendo menores de edad (3). En América Latina el problema sigue la tendencia internacional y en Chile el número de migrantes con diversas nacionalidades ha crecido exponencialmente en los últimos años (4).

Como bien se ha dicho, al ser un determinante social en salud, el problema no es indiferente para quienes ejercemos como enfermeras clínicas o enfermeras investigadoras. Bien sabemos que el contexto en el que las personas vivan y trabajen impactará su salud, al igual que somos conscientes de que los migrantes y refugiados suelen vivir en contextos de pobreza experimentando peores resultados en salud. Por ser agentes de cuidado, es común que trabajemos en primera línea con refugiados o inmigrantes. Este editorial ofrece sugerencias en el trabajo con estos grupos sociales.

En el sistema de salud, las enfermeras clínicas son las principales proveedoras de cuidado y debido a su preparación clínica y profesional poseen las competencias para dar consejería, educar y abogar tanto por individuos como por comunidades. Históricamente, las enfermeras han trabajado con comunidades vulnerables, y en sintonía con ello es que hoy debemos contar con enfermeras capaces de proveer un cuidado sensible a las diferencias culturales, que no sólo contenga bases sólidas en la medicina occidental sino que también se abra a formas de cuidado alternativas/complementarias.

\section{EDUCACIÓN DE ENFERMERÍA EN SALUD GLOBAL}

Con respecto a la enseñanza de las futuras generaciones de enfermeras es necesario educar en mayor conciencia y reflexión cultural, esto será posible en la medida en que reflexionemos sobre nuestros propios prejuicios y estereotipos sobre migrantes y refugiados. Sugerimos, además, que quienes eduquen en el ámbito de la enfermería ofrezcan a los estudiantes la posibilidad de participar en programas internacionales durante su educación de pregrado. Estos programas dan la posibilidad, no sólo de un intercambio cultural sino que también ayudan a reflexionar sobre otras culturas. Ahora bien, es responsabilidad de las enfermeras educadoras 
desarrollar programas y experiencias que ayuden a este fin y a raíz de ello contribuir a encontrar respuestas frente a los desafíos de salud global. Finalmente, debemos invertir en docentes que sean capaces de reconocer la importancia de educar ciudadanos globalizados, con enfoque intercultural y centrados en el paciente.

\section{INVESTIGACIÓN DE ENFERMERÍA EN SALUD}

Sugerimos algunas áreas de investigación para enfermería en salud global, en particular lo relacionado a la salud de migrantes y refugiados. Prioritariamente investigación en el área de estigma asociado a proveer cuidados de salud a migrantes y refugiados, es decir, investigar en cómo los prejuicios de los trabajadores del área de la salud impactan en el cuidado entregado a migrantes y refugiados. Además, es necesario investigar sobre los significados atribuidos a la salud y las prácticas de salud de estos grupos, pues sólo conociendo y describiendo los constructos sociales de salud se podrá entregar un cuidado integral y del mejor nivel. Así también se deben desarrollar intervenciones culturalmente apropiadas para este fin, debemos probar y validar métodos e instrumentos de medición adaptados a dichos grupos sociales. Se debe ser muy riguroso en la adaptación de instrumentos, donde cada uno de los métodos deben ser probados y traducidos a las diversidades culturales de los grupos, pues podría ocurrir que intervenciones que funcionan con grupos específicos no puedan ser traducidas en un contexto distinto, aun siendo el mismo grupo. Debemos recordar que el ambiente influye en la salud y en cómo los grupos experimentan la salud.

En resumen, es esencial empoderar a las enfermeras en sus diversos roles (clínica, docencia e investigación) para que sean capaces de proveer cuidado a migrantes y refugiados. Esta meta se conseguirá únicamente si empoderamos a nuestros estudiantes y comunidades. Los desafíos en salud global son una oportunidad para la investigación en enfermería. Estamos en el umbral de la puerta y debemos tener la voluntad de caminar juntos para atravesarlo para ser capaces de llegar al otro lado.

\section{REFERENCIAS}

1. Koplan JP, Bond TC, Merson MH, Reddy KS, Rodríguez MH, Sewankambo NK, Wasserheit JN, Consortium of Universities for Global Health Executive Board. Towards a common definition of global health. Lancet. 2009; 373(9679): 1993-95.

2. United Nations. Addressing large movements of refuges and migrants [Internet]. New York: United Nations; 2017 [citado 28 abr 2017]. Disponible en: http://refugeesmigrants.un.org/ 
3. Van der Laat C. La migración como determinante social de la salud. En: Cabieses B, Bernales M, McIntyre AM, editores. La migración internacional como determinante social de la salud en Chile: evidencia y propuestas para políticas públicas. Santiago, Chile: Universidad del Desarrollo; 2017. p. 29-38.

4. Sandoval R. Una política migratoria para un Chile cohesionado. En: Cabieses B, Bernales M, McIntyre AM, editores. La migración internacional como determinante social de la salud en Chile: evidencia y propuestas para políticas públicas. Santiago, Chile: Universidad del Desarrollo; 2017. p. 39-49. 


\title{
EDITORIAL
}

\section{GLOBAL HEALTH, NEW CHALLENGES TO NURSING RESEARCH}

\section{SALUD GLOBAL, NUEVOS DESAFÍOS PARA INVESTIGACIÓN EN ENFERMERÍA}

\author{
Dra. LiLian Ferrer \\ School of Nursing. Pontificia Universidad Católica de Chile \\ Dra. Melissa SutherLand \\ Connell School of Nursing. Boston College \\ E-mail: lferrerl@uc.cl, melissa.sutherland@bc.edu
}

Let's talk about global health. It's the buzz word these days. Students want to have a global health experience, a greater number of researchers conduct global health research, and educators are teaching global health principles to their students. So what is global health? And how should we be thinking about it? Global Health as defined by Koplan (1) is "an area for study, research, and practice that places a priority on improving health and achieving equity in health for all people worldwide". Global health is transdisciplinary and collaborative, emphasizes issues that cross national boundaries, focuses on determinants of health and blends individual-focused care with population health. Global health faces many challenges and solutions will require transnational collaborations and partnerships, and the work of multiple disciplines. The United Nations website (2) discusses eighteen global health challenges that we will be facing in the next few decades. An overarching challenge for health care workers specifically is migration; whether than be migration from climate changes, natural disasters, or violence/conflict. In order to address health outcomes from individuals, families, and populations, health care workers will need to address the larger issue of migration in order to provide better care. Specifically, the United Nations (2) defines refugees as individuals protected by international law who are often forced outside of their native country secondary to persecution. In contrast, migrants are considered to be individuals and/or families who voluntarily leave a country or location; regardless of leaving home in search for a better life. Nonetheless, the experience of movement to a new country, community or culture has health care implications for both the country/community of origin and the new place for leaving. Migration, as stated by Carlos Van der Laat (3), is a determinant of health on its own, and currently a main issue in global health. 
Current data support that the largest number of people in history are currently homeless and the global world is witnessing the highest levels of displacement on record. An unprecedented 65.3 million people globally have been forced from home; nearly 21.3 million of these people are refugees and more than half are under the age of 18 (3). Specifically, in Latin America there are large numbers of migrants and refugees, in Chile this has exponentially increased in the past years, with large diversity of countries of origin (4).

Presently as practicing nurses and researchers we need to discuss migration (both voluntary and involuntary) in the context of social determinants of health. We know that where people and populations live and work impacts their health. We also know that migrants and refugees experience poorer health outcomes. As nurses and nurse researchers, we are often at the front lines of care and work with migrant and refugee communities. We are pivotal actors in maintaining and sustaining global health. This editorial offers suggestions to work with migrants and refugees.

Clinical nurses are the main providers of care in the health care system. Because of their educational and clinical preparation, they possess skills for counseling, teaching and advocating at both the individual and community level. Historically, nurses have worked with the most vulnerable communities. In considering nursing practice and migrant and refugee health, we need to provide culturally sensitive care and have nurses able to communicate and understand not only western medicine, but also alternative/complementary ways of care.

\section{NURSING EDUCATION IN GLOBAL HEALTH}

With regards to teaching the future generation of nurses, we need to teach cultural awareness and reflection. This will require us to be reflective of our own biases and stereotypes as they relate to migrants and refugee. Only through our self-awareness we will be able to teach the next generation of nurses culturally sensitive care. We recommend that nurse educators and educational administrators consider offering all students the opportunity to participate in international programs during their undergraduate training. Such programs provide students with opportunities for cultural exchange and reflection. In developing international exchange programs and experiences, nurse educators need to consider best practices for these. Questions of how best to teach and assist students in intercultural experiences need to be answered as address global health challenges. Finally we need to invest in faculty development focused on acknowledging the value of training global citizens, with the end outcome of providing culturally approach and patient center care. 


\section{NURSING RESEARCH IN GLOBAL HEALTH}

We suggest a few areas for global health nursing research and migrants and refugee health. Research on stigma as it relates to providing care for migrants and refugees should be prioritizes. Specifically, we need to investigate how health care workers' stigma impacts care and health outcomes among migrant/refugee patients and communities. Nurse researchers need to investigate the meaning of health and health practices as defined by specific groups. It is only through describing and explicating social constructions of health that nurses will be able to provide the highest level of care. As nurse researchers we also need to develop interventions that are culturally appropriate and specific. We need to test interventions in the intended populations and use measures that have been validated in the study population. We caution researchers about adapting instruments and interventions, without rigorous pre-testing and establishing cultural appropriateness and translation. For instance, an intervention that has worked with a specific group, may not translate to a new setting despite the group being the same. Environment influences health and how groups experience health.

In summary, it is essential to empower nurses in their various roles (practice, education, research) to provide care to migrants and refugees. This goal can only be met when we empower our students and our community. The challenges in global health are an opportunity for nursing research. We are at the door and need to be willing to walk through it with each other to get to the other side.

\section{REFERENCES}

1. Koplan JP, Bond TC, Merson MH, Reddy KS, Rodríguez MH, Sewankambo NK, Wasserheit JN, Consortium of Universities for Global Health Executive Board. Towards a common definition of global health. Lancet. 2009; 373(9679): 199395.

2. United Nations. Addressing large movements of refuges and migrants [Internet]. New York: United Nations; 2017 [cited 2017 Abr 28]. Available from: http:// refugeesmigrants.un.org/

3. Van der Laat C. La migración como determinante social de la salud. En: Cabieses B, Bernales M, McIntyre AM, editores. La migración internacional como determinante social de la salud en Chile: evidencia y propuestas para políticas públicas. Santiago, Chile: Universidad del Desarrollo; 2017. p. 29-38.

4. Sandoval R. Una política migratoria para un Chile cohesionado. En: Cabieses B, Bernales M, McIntyre AM, editores. La migración internacional como determinante social de la salud en Chile: evidencia y propuestas para políticas públicas. Santiago, Chile: Universidad del Desarrollo; 2017. p. 39-49. 